\title{
PREFERENSI PENGHUNI PERUMAHAN DI KOTA PEKANBARU DALAM MENENTUKAN LOKASI PERUMAHAN
}

\author{
Febby Asteriani \\ Fakultas Ekonomi Universitas Islam Riau \\ Jalan Kaharuddin Nasution 113, Pekanbaru Indonesia
}

Diterima 20 September 2010/Disetujui 5 Nopember 2010

\begin{abstract}
Housing development at Pekanbaru city growth rapidly. The phenomenon is happening right now, housing spread sporadically almost all over town, until it is feared will monopolize the land developed. In determining the location of housing, the residents must have the important factors for consideration. This study aims to find out how the site selection factors according to the preferences housing residents. The research uses deductive approach with quantitative methods. The research started from theories that already exist, then look at the condition of the field. Research carried out on housing residents in 5 districts with most dominant amount of housing in Pekanbaru city for five years (2003-2007). The results showed that all the studies about the factors housing site selection are all factors that are considered to determine by housing residents in determining the location of housing, but not all sub-factors are elements that are considered by them.
\end{abstract}

Keywords: housing development, housing residents, housing site selection, land developed

\begin{abstract}
Abstrak: Pembangunan perumahan di kota Pekanbaru berkembang cukup pesat. Fenomena yang terjadi saat ini, perumahan-perumahan menyebar secara sporadis hampir di seluruh penjuru kota, hingga dikhawatirkan akan memonopoli lahan terbangun. Dalam memilih lokasi perumahan, para penghuni pastilah mempunyai faktor-faktor penting sebagai pertimbangan. Penelitian ini bertujuan untuk mengetahui bagaimana faktor-faktor pemilihan lokasi perumahan menurut preferensi penghuni perumahan. Penelitian ini menggunakan pendekatan deduktif dengan metode analisis kuantitatif. Penelitian dimulai dari teori-teori yang sudah ada, kemudian melihat kondisi di lapangan. Untuk penghuni perumahan, sampel ditetapkan terlebih dahulu dan dipilih secara acak. Penelitian dilakukan terhadap penghuni perumahan di lima kecamatan dengan jumlah perumahan paling dominan di kota Pekanbaru selama lima tahun (2003-2007). Hasil analisis menunjukkan bahwa semua kajian tentang faktor-faktor pemilihan lokasi perumahan yang terdapat pada landasan teori merupakan faktor-faktor yang dianggap menentukan oleh penghuni perumahan dalam melakukan pemilihan lokasi perumahan, namun tidak semua sub faktornya merupakan unsur yang menjadi pertimbangan mereka.
\end{abstract}

Kata kunci: pembangunan perumahan, penghuni perumahan, pemilihan lokasi perumahan, lahan terbangun

\section{PENDAHULUAN}

Kota merupakan wadah tempat tinggal/permukiman, kesempatan kerja, kegiatan usaha, kegiatan pemerintahan, dan lain-lain. Perkembangan suatu kota akan sangat dipengaruhi oleh jumlah penduduk dan persebarannya. Pertambahan jumlah penduduk yang pesat di kota dapat disebabkan karena pertumbuhan penduduk alami maupun urbanisasi. Kota Pekanbaru, sebagai ibukota provinsi Riau dengan pertumbuhan ekonominya yang cukup besar, telah memiliki fasilitas-fasilitas perdagangan, per- 
kantoran, pendidikan, permukiman penduduk, serta berbagai fasilitas lainnya. Keadaan ini mendorong penduduk sekitar untuk bermigrasi ke kota tersebut, sehingga menambah jumlah penduduk secara keseluruhan. Pertambahan penduduk yang terus meningkat akan menyebabkan meningkatnya kebutuhan akan rumah/ tempat tinggal. Rumah tidak hanya berfungsi sebagai tempat hunian, namun juga berfungsi sebagai wadah aktivitas interaksi manusia.

Dalam setiap kegiatan pembangunan, masalah pemilihan lokasi maupun pemanfaatan lahan terbangun harus dipertimbangkan secara cermat dan dipilih secara tepat, agar kegiatan tersebut dapat berlangsung secara produktif dan efisien. Pelaksanaan pembangunan yang menyangkut masalah lahan, merupakan masalah yang rumit serta menyangkut berbagai aspek, sehingga dalam penentuan lokasinya memerlukan pertimbangan-pertimbangan yang mendalam.

Perumahan merupakan faktor terpenting dalam kehidupan suatu wilayah, karena kehidupan suatu wilayah akan didukung dengan baik dan tidaknya kehidupan perumahan yang ada dalam wilayah tersebut. Perkembangan perumahan yang pesat akan mendukung pertumbuhan pembangunan suatu wilayah. Hal tersebut merupakan dampak positif dari pembangunan perumahan, akan tetapi jika pertumbuhan perumahan yang pesat tersebut tidak diatur, akan menimbulkan kesemrawutan penataan pembangunan yang baik. Oleh karena itu butuh adanya suatu kebijakan untuk mengatur pertumbuhan tersebut.

Kendala yang muncul dari perumahan akan juga menghambat perkembangan pembangunan suatu wilayah. Hal ini dikarenakan kendala perumahan akan berpengaruh besar terhadap kehidupan penghuni perumahan tersebut. Unsur terpenting dalam pertumbuhan pembangunan suatu wilayah adalah aktor pelakunya, sehingga permasalahan suatu perumahan merupakan faktor yang penting untuk menunjang keberlangsungan kehidupan suatu wilayah.

Pembangunan perumahan di Indonesia akhir-akhir ini semakin berkembang pesat. Perkembangan perumahan di kota Pekanbaru, sebagai kota yang menjadi objek penelitian di- mulai sejak tahun 2003 hingga saat ini. Fenomena yang terlihat saat ini di kota Pekanbaru yakni masih banyaknya pembangunan perumahan yang telah siap namun belum diguna$\mathrm{kan}$, tetapi investor terus saja melakukan investasi dalam pembangunan perumahan. Kondisi ini menimbulkan kekhawatiran bahwa perumahan-perumahan tersebut akan memonopoli lahan terbangun, selain itu juga menjadikan tanah berkembang menjadi komoditi perdagangan dan sarana investasi. Hal ini jika tidak disikapi dengan baik oleh pemerintah daerah kota Pekanbaru sejak saat ini, dikhawatirkan akan terjadi inefisiensi lahan dan akan menimbulkan masalah dalam penataan tata ruang di kota Pekanbaru. Pihak yang terlibat langsung dengan perumahan adalah investor maupun penghuni perumahan itu sendiri. Dalam melakukan pemilihan lokasi perumahan, pastilah para calon penghuni memiliki preferensi tentang faktor-faktor yang menjadi pertimbangan mereka dalam melakukan pemilihan lokasi perumahan.

Rumah merupakan salah satu kebutuhan dasar manusia di samping pangan, sandang, pendidikan, dan kesehatan. Selain berfungsi sabagai pelindung terhadap gangguan alam/cuaca dan makhluk lainnya, rumah juga memiliki peran sosial budaya sebagai pusat pendidikan keluarga, persemaian budaya dan nilai kehidupan, penyiapan generasi muda, dan sebagai manifestasi jati diri. Bagi banyak masyarakat Indonesia terutama golongan menengah ke bawah, rumah juga dapat merupakan barang modal (capital goods), karena dengan aset rumah ini mereka dapat melakukan kegiatan ekonomi di dalam mendukung kehidupan dan penghidupannya. (KEPMEN Kimpraswil, 2002).

Dalam UU Nomor 4 tahun 1992 tentang perumahan dan permukiman, dijelaskan bahwa rumah adalah bangunan yang berfungsi sebagai tempat tinggal atau hunian dan sarana pembinaan keluarga. Perumahan adalah kelompok rumah yang berfungsi sebagai lingkungan tempat tinggal atau lingkungan hunian yang dilengkapi dengan prasarana dan sarana lingkungan. Permukiman adalah bagian dari lingkungan hidup di luar kawasan perkotaan maupun perdesaan yang berfungsi sebagai lingkungan tempat tinggal atau lingkungan hunian dan tempat kegiatan yang mendukung perikehidupan dan penghidupan. 
Aca Sugandhi (2005) menyebutkan bahwa kebijakan pemerintah dalam penyelenggaraan perumahan dan permukiman diarahkan agar setiap orang atau keluarga di Indonesia mampu memenuhi kebutuhan rumah yang layak dan terjangkau pada lingkungan yang sehat, aman, harmonis dan berkelanjutan dalam upaya terbentuknya masyarakat yang berjati diri, mandiri dan produktif. Untuk mewujudkan kondisi tersebut, pemenuhan kebutuhan rumah dengan lingkungan yang sehat harus secara konsepsional ditempuh melalui pembangunan baru dan peningkatan kualitas lingkungan sehingga tercipta pembangunan perkotaan yang secara ekologis berkelanjutan (livable, habitable, and sustainable city). Pembangunan rumah yang sehat harus diikuti pula dengan pembangunan lingkungan perumahannya melalui penyediaan prasarana dan sarana dasar (PSD) yang memadai, khususnya air minum, sanitasi lingkungan, jalan dan listrik. Pemenuhan prasarana dasar tersebut diyakini besar kontribusinya dalam meningkatkan kesehatan lingkungan dan dalam menunjang pertumbuhan ekonomi.

Penataan perumahan dan permukiman bertujuan untuk: (1) Memenuhi kebutuhan rumah sebagai salah satu kebutuhan dasar manusia, dalam rangka peningkatan dan pemerataan kesejahteraan rakyat; (2) Mewujudkan perumahan dan permukiman yang layak dalam lingkungan yang sehat, aman, serasi, dan teratur; (3) Memberi arah pada pertumbuhan wilayah dan persebaran penduduk yang rasional; (4) Menunjang pembangunan di bidang ekonomi, sosial, budaya, dan bidang-bidang lain.

Luhst dalam Febby (2008) menyebutkan bahwa kualitas kehidupan yang berupa kenyamanan, keamanan dari suatu rumah tinggal sangat ditentukan oleh lokasinya, dalam arti daya tarik dari suatu lokasi ditentukan oleh dua hal yaitu lingkungan dan aksesibilitas. Lingkungan oleh Luhst didefinisikan sebagai suatu wilayah yang secara geografis dibatasi dengan batas nyata, dan biasanya dihuni oleh kelompok penduduk. Lingkungan mengandung unsur-unsur fisik dan sosial yang menimbulkan kegiatan dan kesibukan dalam kehidupan sehari-hari. Unsur-unsur tersebut berupa gedunggedung sekolah, bangunan pertokoan, pasar, daerah terbuka untuk rekreasi, jalan mobil, dan sebagainya.

Aksesibilitas menurut Luhst merupakan daya tarik suatu lokasi dikarenakan akan memperoleh kemudahan dalam pencapaiannya dari berbagai pusat kegiatan seperti pusat perdagangan, pusat pendidikan, daerah industri, jasa pelayanan perbankan, tempat rekreasi, pelayanan pemerintahan, jasa profesional dan bahkan merupakan perpaduan antara semua kegiatan tersebut. Penilaian dari aksesibilitas bisa berupa jarak dari Central Business Distrik atau CBD, kemudahan mendapat pelayanan dari transportasi umum yang menuju lokasi bersangkutan atau bisa juga dilihat dari lebar jalan yaitu semakin sempit lebar jalan suatu lahan, maka berarti aksesibilitas dari tempat yang bersangkutan kurang baik.

Koestoer (2001) lebih menekankan pada faktor aksesibilitas sebagai pengaruh utama dalam memilih lokasi tempat tinggal yaitu kemudahan transportasi dan kedekatan jarak. Koestoer berpendapat bahwa terdapat hubungan yang sangat erat antara ketersediaan angkutan umum lokal dengan pertumbuhan lokasi tempat tinggal, adanya pelayanan angkutan umum menyebabkan kemudahan dalam mencapai lokasi tempat tinggal yang berada di daerah pinggiran kota, sehingga semakin baik pelayanan transportasi akan mempengaruhi pertumbuhan suatu lingkungan permukiman.

Lebih lanjut Shinta (2002) mengemukakan beberapa faktor pemilihan lokasi perumahan yang berbeda, sesuai dengan tipe perumahan. Untuk tipe rumah sederhana adalah faktor masyarakat (harga rumah dan kemudahan sistem pembayaran) karena masyarakat yang memilih tipe rumah sederhana ini pada umumnya berasal dari masyarakat golongan rendah sampai menengah, lingkungan (kedekatan terhadap tempat kerja, kemudahan angkutan umum), jejaring (air bersih) dan tata letak perumahan. Untuk tipe rumah menengah adalah faktor manusia (keamanan), lingkungan (kedekatan terhadap fasilitas perbelanjaan, pendidikan, dan lain-lain), jejaring (jaringan air bersih). Sedangkan untuk tipe rumah mewah adalah lingkungan alam (kesejukan udara, kemudahan memsperoleh air bersih), manusia (kebersihan, keindahan dan keamanan), masyarakat (nilai prestise perumahan), lindungan (bentuk dan 
kualitas bangunan rumah), fasilitas yang tersedia serta faktor jejaring (jaringan air bersih) dan letak lokasi perumahan.

Ehwan (2004) mengatakan faktor lokasi menjadi pertimbangan penting dalam pemilihan perumahan. Faktor lain yang dipertimbangkan oleh konsumen adalah aspek lingkungan, fisik rumah, fungsi rumah dan kedekatan dengan berbagai fasilitas perkotaan lainnya. Selain itu kondisi lingkungan yang asri, udara segar, ketersediaan air bersih, kenyamanan dan kondisi lingkungan yang aman akan menjadi pertimbangan konsumen.

Simanungkalit (2010) menyebutkan bahwa setiap orang mempunyai faktor yang berbeda dalam prioritas pertimbangan untuk memilih perumahan, sesuai dengan usia, kecenderungan, selera, tingkat penghasilan, dan aktivitas masing-masing. Bagi keluarga muda, biasanya harga menjadi pertimbangan utama. Pembelian rumah umumnya dilakukan dengan dukungan fasilitas Kredit Perumahan Rakyat (KPR). Jadi, dengan harga rumah yang lebih murah, cicilan KPR yang harus mereka bayar setiap bulan juga kecil. Bagi pasangan yang mulai mapan, kemungkinan harga bukan lagi menjadi faktor utama. Bagi pasangan mapan dan pensiunan, cenderung memilih rumah ekslusif dan sangat mengutamakan privasi.

Perumahan ideal adalah yang dilengkapi dengan berbagai sarana dan prasarana (Ana, 2010). Fasilitas sarana dan prasarana yang lengkap merupakan alat bantu bila kita tinggal di suatu wilayah. Perlu dilihat fasilitas umum dan fasilitas sosial yang ditawarkan oleh pihak pengembang.

Ana (2010) menyebutkan ada beberapa hal yang perlu diperhatikan adalah: (1) Jalan lingkungan, apakah cukup lebar. Paling tidak untuk dua mobil yang bersimpangan; (2) Saluran drainase/selokan, apakah memenuhi kriteria karena mempunyai suatu elevasi tertentu sehingga tidak menyebabkan comberan tergenang di depan rumah kita dan juga perlu diperhatikan apakah kira-kira akan mampu mengalirkan air hujan; (3) Penerangan jalan; (4) Fasilitas air minum; (5) Air bersih. Seperti diketahui, tidak semua wilayah mempunyai air tanah yang layak digunakan. Oleh karena itu perlu diperhatikan apakah ada saluran PAM atau sarana lain pemasok air layak pakai; (6) Jaringan telepon; dan (5) Toko atau pasar untuk kebutuhan hidup sehari-hari.

Sedangkan fasilitas sosial yang perlu diperhatikan adalah rumah ibadah (mushalla, masjid, gereja dan lainnya), lapangan olah raga, taman ataupun areal terbuka lainnya untuk umum, pos keamanan, balai pertemuan untuk lingkup RT/RW dan sebagainya. Kelengkapan fasilitas umum dan sosial tersebut akan membuat kita nyaman dan betah tinggal di suatu lokasi perumahan. Perlu dilakukan pengecekan langsung ke lokasi perumahan dan lingkungan yang ada di luar lokasi perumahan. Selain itu, ada beberapa faktor penting lain yang perlu diperhatikan sewaktu akan memilih lokasi perumahan, yaitu: (1) Menanyakan aspek legalitas dari lokasi perumahan. Bila sudah menemukan lokasi atau kawasan yang sesuai, maka perlu ditanya secara detail mengenai aspek legalitas. Misalnya: sertifikat induk untuk lokasi suatu kawasan perumahan yang dipilih. Hal ini untuk mengetaui kepastian dan kebsahan kepemilikan atas tanah yang nantinya akan dikembangkan; (2) Kondisi fisik rumah. Kondisi aktual rumah harus sesuai dengan gambar atau brosur (spesifikasinya).

Berdasarkan kajian pustaka di atas, selanjutnya akan dijadikan landasan teori dalam penyusunan penelitian ini. Kumpulan teori-teori memuat faktor-faktor yang menjadi pertimbangan dalam melakukan pemilihan lokasi perumahan yaitu aksesibilitas (jarak, kondisi fisik jalan, transportasi), kelengkapan sarana prasarana, kondisi lingkungan, kondosi sosial ekonomi, kondisi fisik wilayah, kualitas perumahan, kependudukan, kelengkapan fasilitas perumahan, aspek legalitas perumahan, aspek teknis pelaksanaan, dan aspek kesehatan.

Tujuan dari penelitian ini adalah: (1) Mengkonfirmasikan faktor-faktor teoritis tentang pemilihan lokasi perumahan di lapangan. (2) Mengetahui faktor-faktor yang dianggap menentukan/tidak dalam pemilihan lokasi. Sedangkan manfaat yang diharapkan dapat diperoleh yaitu: (1) Sebagai salah satu sumber informasi, yang dapat digunakan oleh pemerintah daerah kota Pekanbaru dalam menentukan kebijakan dan implementasinya, yang berkaitan dengan pemanfaatan lahan di kota Pekanbaru; 
dan (2) Sebagai salah satu bahan pertimbangan bagi kalangan dunia usaha dalam melakukan investasi dan memilih lokasi perumahan yang sesuai.

\section{METODE PENELITIAN}

\section{Metode Pendekatan}

Dalam penelitian ini digunakan pendekatan deduktif dengan metode analisis kuantitatif. Penelitian dimulai dari teori-teori yang sudah ada kemudian melihat kenyataan di lapangan. Sesuai dengan tujuan penelitian, maka terlebih dahulu dilakukan pemantapan teori yang berkaitan dengan faktor-faktor yang menentukan dalam pemilihan lokasi perumahan. Selanjutnya ditetapkan variabel-variabel penelitian, yang kemudian dibuktikan di lapangan dan dilakukan melalui pengajuan kuesioner tipe pilihan kepada responden, yaitu penghuni perumahan di kota Pekanbaru.

\section{Jenis dan Teknik Pengumpulan Data}

(1) Data primer. Data primer merupakan data yang diperoleh dari pengamatan lapangan dan hasil pengajuan kuesioner yang bersifat semi terbuka dari para responden (penghuni perumahan). Kuesioner yang diajukan kepada para responden merupakan kuesioner tipe pilihan. Tipe pengukuran yang digunakan adalah itemized rating scale. Tipe pengukuran ini menyediakan pilihan sesuai dengan kebutuhan. Dalam penelitian ini digunakan 4 tipe pilihan. Responden diminta untuk memberikan penilaian 1-4 mengenai faktor-faktor dalam melakukan pemilihan lokasi perumahan dengan memberi tanda silang pada pilihan jawaban yang telah tersedia: 1 = Sangat Tidak Menentukan (STM), 2 = Tidak Menentukan (TM), 3 = Menentukan (M), 4 = Sangat Menentukan (SM).

(2) Data sekunder. Merupakan data yang diperoleh dari dokumen-dokumen tertulis seperti data prasarana, transportasi, IMB, dan lain-lain.

(3) Teknik Pengambilan Sampel. Untuk jumlah penghuni perumahan, penelitian dilakukan terhadap 5 kecamatan dengan jumlah perumahan paling dominan di kota Pekanbaru selama 5 tahun terakhir (2003-2007). Penentuan jumlah sampel menggunakan Tabel Arkin dan Raymond. Karena jumlah populasi dalam setiap kelurahan tidak sama, maka jumlah sampel dari setiap populasi dihitung secara proporsional. Penentuan responden menggunakan teknik simple random sampling. Hasil Perhitungan jumlah sampel dan jumlah unit perumahan dapat dilihat di Lampiran pada Tabel 1 dan Tabel 2.

Berdasarkan kajian pustaka, variabel penelitian dapat dilihat di Lampiran Gambar 1. Langkah-langkah dalam menganalisis data yang diperoleh yaitu: (1) Menyusun jawaban responden ke dalam tabel. Pendistribusian nilai jawaban penghuni perumahan dikelompokkan menurut faktor-faktor yang telah ditetapkan; (2) Untuk mengetahui preferensi penghuni perumahan terhadap faktor pemilihan lokasi perumahan digunakan perhitungan rating scale (Sugiyono, 2000).

\section{HASIL DAN PEMBAHASAN}

\section{Analisis Preferensi Penghuni Perumahan terhadap Faktor-faktor Pemilihan Lokasi Perumahan}

Dari hasil penelitian yang dilakukan di lima kecamatan dengan jumlah unit perumahan paling dominan di kota Pekanbaru, diperoleh 182 responden penghuni perumahan. Sebanyak 18 responden gugur karena beberapa sebab, di antaranya yaitu sedang tidak berada di tempat, tidak bersedia diteliti, dan kuisioner tidak dikembalikan. Langkah selanjutnya mengalikan persentase jumlah responden setiap variabel dengan nilai 1 sampai 4 yang dipilih (Lampiran Tabel 3).

Jumlah kriterium data (jika mendapatkan nilai 4/point tertinggi) adalah: 34.944 . Diperoleh dari hasil perkalian (182 x 4 x 48). 182 adalah jumlah responden, 4 adalah nilai tertinggi yang dipilih, dan 48 adalah jumlah variabel. (Gambar 2).

Contoh hitungan untuk variabel pertama: Total nilai yang diperoleh untuk variabel pertama adalah: $[(9 \times 1)+(141 \times 2)+(24 \times 3)+(8 \times 4)] \times 48=$ 18960, maka variabel pertama termasuk ke dalam kategori tidak menentukan (TM).

Berdasarkan hasil perhitungan di atas, dari 


\begin{tabular}{|c|c|c|c|c|c|}
\hline STM & & $\mathrm{TM}$ & & $\mathrm{M}$ & \\
\hline$\longmapsto$ & $\mathrm{I}$ & $\mathrm{T}$ & $\mathrm{I}$ & $\mathrm{I}$ & \\
\hline 8736 & 13104 & 17472 & 21840 & 26208 & 30576 \\
\hline
\end{tabular}

Gambar 2. Kriterium Data

48 variabel yang ada, hanya 23 variabel yang merupakan unsur dalam faktor pemilihan lokasi Perumahan dari sudut pandang penghuni perumahan. Untuk lebih jelasnya dapat dilihat di Lampiran pada Tabel 4.

\section{Analisis Faktor-Faktor Pemilihan Lokasi Perumahan}

\section{Aksesibilitas}

(1) Jarak

(a) Kedekatan terhadap jalan utama. Jalanjalan utama yang melalui pusat kota Pekanbaru dan merupakan jalur utama dari pusat kota adalah sistem primer dalam konteks sistem jaringan jalan yang melayani kegiatan pergerakan wilayah atau antarkota. Kenyataan di lapangan menunjukkan bahwa lokasi perumahan yang menjadi objek penelitian, beberapa di antaranya berada di jalan-jalan utama di kota Pekanbaru dan sebagian besar lainnya berada dekat dengan jalan utama. Dari 29 jalan utama yang terdapat di kota Pekanbaru, 5 jalan utama merupakan ruas jalan tempat lokasi perumahan jalan $4 \mathrm{~m}$ dan maksimal jalan $14 \mathrm{~m}$. Ruas-ruas jalan tempat lokasi perumahan pada umumnya berada pada jalan dengan ruas jalan 1 jalur searah dan 2 jalur dua arah. Lokasi perumahan dengan jumlah paling dominan berada di ruas jalan 2 jalur 2 arah yaitu di Jalan Hangtuah (853 unit), dengan lebar jalan $14 \mathrm{~m}$. Indikasi ini menunjukkan bahwa lebar jalan juga merupakan unsur yang menentukan penghuni perumahan dalam memilih lokasi perumahan karena lebar jalan berkaitan dengan kapasitas kendaraan yang bisa melewati ruas jalan tersebut. Semakin lebar ruas jalan, maka semakin banyak kapasitas kendaraan yang bisa melewati ruas jalan tersebut.

\section{(3) Transportasi}

(a) Transportasi Umum. Pertimbangan terhadap transportasi umum ini adalah dalam hal kemudahan memperoleh angkutan umum, baik dari segi biaya, waktu maupun frekuensinya. Angkutan umum sebagai model transportasi massa di kota Pekanbaru dilayani oleh angkutan umum dengan trayek tetap yaitu angkutan 
rakat umum pada tahun 2003 berkisar antara Rp1.000,00 - Rp1.200,00. Bagi mahasiswa atau pelajar dikenai biaya Rp500,00. Sedangkan untuk tahun 2007, tarif angkutan umum untuk masyarakat adalah Rp2.100,00 dan untuk mahasiswa Rp1.500,00. Untuk angkutan umum jenis tidak dalam trayek di kota Pekanbaru meliputi; taxi, bajaj, dan ojek, dalam pentarifan ada yang memakai argo berdasarkan kilometer yang ditempuh penumpang maupun harga carteran kesepakatan antara penumpang dan pengemudi. Selain itu tersedia pula angkutan umum bajaj dengan kapasitas 2 orang dan ojek berkapasitas 1 orang. Angkutan ini beroperasi di bagian kota Pekanbaru dan sistem pentarifan tergantung kesepakatan antara penumpang dan pengemudi.

Kondisi saat ini menunjukkan bahwa angkutan umum di kota Pekanbaru sudah cukup memadai namun masih perlu terus dikembangkan agar masyarakat bisa dengan mudah mengakses fasilitas umum dan fasilitas kota.

(b) Transportasi Pribadi. Hasil pengamatan secara visual di lapangan menunjukkan bahwa hampir seluruh lokasi perumahan di wilayah penelitian cukup nyaman untuk kendaraan pribadi karena adanya ketersediaan tempat parkir dan jarak yang dekat dengan tempat parkir yaitu parkir langsung di halaman rumah maupun ruas jalan di dekat perumahan tersebut.

\section{Kelengkapan Sarana Prasarana}

(1) Tersedianya Jaringan Listrik. Kondisi di lapangan menunjukkan bahwa daerah penelitian merupakan wilayah yang sudah terjangkau fasilitas jaringan listrik. Hasil wawancara singkat dengan seluruh penghuni perumahan menunjukkan bahwa seluruh rumah penghuni perumahan telah difasilitasi jaringan listrik dari PLN. Kapasitasnya cukup bervariasi, tergantung pada tipe perumahan yaitu 450VA, 900VA dan 1200VA.

Untuk masyarakat di perkotaan, pemenuhan prasarana listrik merupakan salah satu pemenuhan kebutuhan dasar yang digunakan baik oleh rumah tangga, industri, usaha perdagangan, perkantoran, penerangan jalan, fasilitas umum dan kebutuhan lainnya. Tanpa adanya jaringan listrik, maka hampir dapat dipastikan bahwa kegiatan masyarakat akan terganggu.
(2) Tersedianya jaringan jalan. Jaringan jalan pada dasamya bersifat prasarana pelayanan untuk memudahkan pergerakan orang dan barang dari tempat asal ke tempat tujuan. Pergerakan orang/barang tersebut terjadi sebagai akibat adanya proses pemenuhan kebutuhan di tempat asal yang perlu dipenuhi oleh kegiatan di tempat tujuan. Pergerakan yang timbul sangat dipengaruhi oleh besarnya kebutuhan (demand) serta ketersediaan (supply) yang ada.

Sejak tahun 2003-2007 di kecamatan Tampan dan kecamatan Tenayan Raya mengalami penambahan panjang jaringan jalan yang cukup pesat, khususnya untuk penambahan jalan dengan jenis permukaan aspal. Penambahan pembangunan jaringan jalan ini memacu pertumbuhan perumahan yang pesat di kedua kecamatan tersebut, yang menjadi tempat/kecamatan dengan jumlah perumahan paling dominan di kota Pekanbaru.

Indikasi ini menunjukkan bahwa dengan bertambahnya jaringan jalan kota akan membuka wilayah-wilayah baru dan tumbuhnya kawasan permukiman, perdagangan, industri dan jasa yang menjadi daya tarik penduduk untuk masuk dan tinggal pada kawasan tersebut.

(3) Tersedianya Jaringan Air Bersih. Penyediaan prasarana air bersih ini merupakan kebutuhan dasar kesehatan masyarakat. Penyediaan prasarana ini bertujuan untuk memenuhi kebutuhan domestik atau kebutuhan rumah tangga bagi warga masyarakat. Selain itu juga diperlukan untuk memenuhi kebutuhan air pada berbagai fasilitas perkotaan seperti fasilitas umum, fasilitas perdagangan maupun untuk memenuhi kebutuhan industri.

Kondisi air bersih di kota Pekanbaru tidak cukup bagus karena berwarna kekuningkuningan yang bersumber dari Sungai Siak, sehingga sebagian besar rumah difasilitasi dengan sumur bor. Hanya beberapa rumah di pusat kota yang menggunakan PDAM sebagai sumber air bersih mereka. Hasil wawancara singkat dengan setiap penghuni perumahan yang menjadi objek penelitian menunjukkan bahwa hampir seluruh responden (175 orang) menggunakan sumur bor sebagai sumber air bersih, dan sisanya menggunakan sumur biasa.

Indikasi ini menunjukkan bahwa para 
penghuni perumahan mempertimbangkan ketersediaan air bersih sewaktu melakukan pemilihan lokasi perumahan karena sebagian besar penghuni perumahan menggunakan sumur bor untuk mendapatkan air bersih bagi kehidupan mereka dikarenakan kondisi air bersih di kota Pekanbaru yang masih kurang baik dan berwarna kekuning-kuningan.

(4) Tersedianya Jaringan Drainase. Ketersediaan jaringan Drainase di lokasi perumahan dianggap menentukan oleh responden perumahan dalam menentukan lokasi perumahan, karena jaringan ini erat kaitannya dengan kebersihan dan kesehatan lingkungan. Untuk pembuangan limbah cair rumah tangga, sangatlah dibutuhkan ketersediaan jaringan drainase ini agar limbah cair tersebut tidak menggenangi perumahan tersebut. Kondisi di lapangan menunjukkan bahwa lokasi perumahan yang menjadi objek penelitian pada umumnya sudah dilengkapi dengan sistem drainase, baik drainase terbuka maupun tertutup, dengan dimensi yang bervariasi.

\section{Kondisi Lingkungan}

(1) Keamanan. Keamanan merupakan sub faktor yang dianggap menentukan oleh penghuni perumahan dalam menentukan lokasi perumahan. Kondisi keamanan wilayah penelitian dapat dilihat dari tingkat kejahatannya (persentase jumlah kejahatan terhadap jumlah penduduk). Dari lima kecamatan penelitian yang menjadi lokasi perumahan pernah terjadi pencurian di kecamatan tersebut, namun nihil perampokan di tiga kecamatan (Tampan, Rumbai dan Marpoyan Damai). Persentase tingkat kejahatan, (pencurian dan perampokan) terhadap jumlah penduduk untuk kecamatan penelitian juga cukup rendah.

(2) Kenyamanan. Kenyamanan dalam faktor lingkungan dianggap menentukan oleh penghuni perumahan dalam menentukan lokasi perumahan. Hasil Kuisioner responden menunjukkan bahwa hampir seluruh penghuni perumahan (155 responden) merasakan kenyamanan dengan lingkungan mereka.

\section{Kondisi Sosial Ekonomi}

(1) Harga Perumahan. Hampir seluruh responden (175 orang) menganggap bahwa harga rumah dianggap menentukan mereka dalam menentukan lokasi perumahan. Dalam melaku- kan pemilihan terhadap lokasi perumahan, para penghuni perumahan harus menyesuaikan dengan kemampuan ekonomi mereka. Kondisi di lapangan menunjukkan harga perumahan di kota Pekanbaru cukup bervariasi dan tergantung pada tipe perumahan. Untuk tipe 36, harga perumahan berkisar antara Rp55-70 juta. Tipe 54 berkisar antara Rp250-300 juta dan tipe 75 seharga Rp 350 juta. Semakin berada dekat dengan pusat kota, harga rumah cenderung menjadi semakin mahal. Hasil penelitian di lapangan menunjukkan bahwa para responden umumnya membeli rumah dengan harga menengah.

(2) Kemudahan pengajuan kredit. Pada umumnya sistem pembayaran perumahan di kota Pekanbaru biasanya dilakukan dengan sistem perkreditan/KPR oleh bank tertentu, sehingga dapat membantu para penghuni perumahan yang ingin membeli rumah. ataupun melalui pembayaran secara cash. Hasil wawancara singkat dengan penghuni perumahan menunjukkan bahwa hampir seluruh responden penghuni perumahan (179 responden) membayar pembelian rumah dengan sistem perkreditan oleh bank. Indikasi ini menunjukkan bahwa kemudahan sistem pembayaran rumah menjadi pertimbangan penting yang menentukan mereka dalam menentukan lokasi perumahan.

\section{Kondisi Fisik Wilayah}

Kondisi di lapangan menunjukkan bahwa semua lokasi perumahan yang menjadi objek penelitian berada di wilayah datar karena memang kondisi topografi di kota Pekanbaru relatif datar. Secara umum kondisi wilayah kota Pekanbaru merupakan dataran rendah dengan kemiringan lereng 0-2 persen, kecuali beberapa tempat di bagian utara dan timur memiliki morfologi yang bergelombang dengan kemiringan di atas 40 persen. Kondisi topografi ini memungkinkan kota Pekanbaru untuk mudah dikembangkan, terbukti bahwa kota ini telah tiga kali mengalami pemekaran wilayah. Selain itu juga berpotensi untuk menjadi kawasan perdagangan.

\section{Kualitas Perumahan}

Faktor kualitas perumahan merupakan faktor yang dianggap menentukan penghuni perumahan dalam melakukan pemilihan terhadap lokasi perumahan. Faktor ini terdiri dari unsur 
spesifikasi perumahan dan desain perumahan. Tetapi hanya sub faktor spesifikasi perumahan yang dianggap menentukan oleh penghuni perumahan dalam melakukan pemilihan lokasi perumahan. Untuk Tipe 36, spesifikasi perumahan pada umumnya: Atap seng/genteng metal, lantai ACI/keramik, sumur bor, listrik 900VA. Untuk tipe 50: Atap genteng, lantai keramik, sumur bor, listrik $1300 \mathrm{VA}$. Hasil wawancara dengan para responden menunjukkan bahwa sebagian besar responden merasa cukup puas dengan spesifikasi perumahan mereka mahan. Hasil penelitian menunjukkan bahwa seluruh responden menganggap bahwa faktor ini menentukan dalam pemilihan lokasi perumahan. Aspek legalitas perumahan mereka adalah berupa sertifikat induk untuk lokasi perumahan. Hal ini berguna untuk mengetahui kepastian dan keabsahan kepemilikan tanah yang akan dikembangkan. Kondisi di lapangan menunjukkan bahwa sebagian besar responden (158 orang) telah menanyakan sertifikat induk lokasi perumahan mereka kepada pengembang perumahan untuk mendapatkan kepastian all upe menteryall (upe tu ne alas). Hlumasi menunjukkan bahwa kelengkapan fasilitas umum dianggap menentukan oleh responden penghuni perumahan dalam menentukan lokasi perumahan.

\section{Aspek Legalitas Perumahan}

Faktor legalitas perumahan dianggap menentukan oleh responden penghuni perumahan dalam menentukan lokasi perumahan. Faktor ini terdiri dari unsur keabsahan kepemilikan peru-

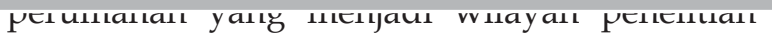
berada jauh dari lokasi pabrik. Lokasi pabrik di kota Pekanbaru terdapat di bagian pinggir kota di kecamatan Rumbai, yang merupakan kecamatan dengan jumlah perumahan paling sedikit. Sehingga hampir semua lokasi perumahan ini merupakan lokasi yang bebas dari polusi baik polusi udara, polusi air, dan polusi lainnya yang dapat ditimbulkan oleh pabrik.

(2) Lokasi sebaiknya tidak terlalu terganggu 
kebisingan. Hasil wawancara dengan para responden menunjukkan bahwa lokasi mereka tidak terganggu kebisingan karena letaknya yang jauh dari terminal maupun pabrik. Indikasi ini menunjukkan bahwa penghuni perumahan rumah umumnya berada di kawasan yang tidak terlalu terganggu kebisingan.

\section{Temuan Penghuni Perumahan}

Hasil analisis yang dilakukan terhadap 182 responden penghuni perumahan di kota Pekanbaru, semua faktor pemilihan lokasi perumahan yang terdapat dalam tinjauan pustaka tersebut memang merupakan faktor yang dianggap menentukan oleh para penghuni perumahan penelitian dalam melakukan pemilihan terhadap lokasi perumahan, tetapi tidak semua variabel/subfaktor dari faktor tersebut dianggap menentukan.

Di antara faktor-faktor pemilihan lokasi perumahan tersebut, ada faktor yang sangat menentukan penghuni perumahan maupun faktor yang menentukan penghuni perumahan dalam melakukan pemilihan lokasi perumahan. Hasil analisis menunjukkan bahwa faktor kelengkapan prasarana (tersedianya jaringan listrik dan air bersih), faktor sosial ekonomi (harga perumahan), dan faktor legalitas perumahan (keabsahan kepemilikan perumahan), merupakan faktor yang sangat menentukan penghuni perumahan dalam memilih lokasi perumahan, sedangkan faktor yang dianggap menentukan adalah faktor aksesibilitas yaitu sub faktor jarak (kedekatan terhadap jalan utama), kondisi fisik jalan (kualitas permukaan jalan dan lebar jalan), transportasi (transportasi umum dan transportasi pribadi), faktor kelengkapan prasarana (tersedianya jaringan jalan dan drainase), faktor kondisi lingkungan (keamanan dan kenyamanan), faktor kondisi sosial ekonomi (harga perumahan dan kemudahan pengajuan kredit), faktor kondisi fisik wilayah (topografi), faktor kualitas perumahan (spesifikasi perumahan), faktor kependudukan (jumlah penduduk), faktor kelengkapan fasilitas perumahan (kelengkapan fasilitas umum), faktor teknis pelaksanaan (bukan daerah banjir, kemudahan pencapaian tanpa hambatan yang berarti, kondisi tanah baik) dan faktor kesehatan (lokasi sebaiknya jauh dari lokasi pabrik yang dapat mendatangkan polusi, lokasi sebaiknya tidak terlalu terganggu kebisingan).

\section{SIMPULAN}

Semua kajian tentang faktor-faktor pemilihan lokasi perumahan yang terdapat pada landasan teori merupakan faktor-faktor yang dianggap menentukan oleh penghuni perumahan, namun tidak semua sub faktor yang terkandung dalam setiap faktor tersebut dianggap menentukan. Dalam menilai faktor-faktor pemilihan lokasi perumahan, pada umumnya terjadi persamaan preferensi diantara para penghuni perumahan. Hampir semua sub faktor yang dianggap menentukan dan sub faktor yang dianggap tidak menentukan, terjadi persamaan preferensi di antara para penghuni perumahan.

Saran. Dengan mengacu pada hasil analisis dan pembahasan serta permasalahan yang muncul, berikut ini beberapa saran yang perlu dijadikan rekomendasi, antara lain: (1) Bagi penghuni perumahan, hendaknya memperhatikan faktor-faktor pemilihan lokasi perumahan di atas dalam menentukan pemilihan lokasi perumahan, agar penghuni memperoleh kemudahan dalam aksesibilitas maupun kelengkapan sarana prasarana, kenyamanan lingkungan serta faktor-faktor lainnya; (2) Bagi investor perumahan, hendaknya memperhatikan faktorfaktor pemilihan lokasi perumahan di atas dalam menentukan pemilihan lokasi perumahan yang akan dibangun, agar perumahan yang telah dibangun dapat dijual. Selain mempertimbangkan faktor harga tanah dan kelengkapan sarana prasarana, hendaknya pengembang juga memperhatikan beberapa faktor penting lainnya seperti: aksesibilitas, lingkungan, kependudukan dan aspek teknis pelaksanaan. (3) Bagi pemerintahan daerah: (a) Sebagai instansi yang berwenang mengeluarkan perizinan bangunan, hendaknya pemerintah kota mempunyai suatu peraturan yang dijadikan acuan dalam memberikan izin pembangunan perumahan kepada investor perumahan, agar tercipta interaksi ekonomi dan mencegah terjadinya inefisiensi lahan. (b) Untuk jangka panjang, pemerintah kota perlu mengkaji secara cermat peruntukan lahan yang mengacu pada kebu- 
tuhan sebuah kota sebagai bagian dari pemanfaatan lahan, khususnya untuk kawasan perumahan agar tidak terjadi monopoli dalam pemanfaatan lahan terbangun oleh pembangunan perumahan, karena telah begitu banyaknya perumahan yang menyebar secara sporadis di kota Pekanbaru yang dapat menimbulkan ketimpangan ekonomi dan gap sosial diantara masyarakat. (c) Dalam hal perencanaan, pemerintah kota perlu merencanakan penataan penyebaran lokasi perumahan baru, agar dapat mencegah pertumbuhan perumahan yang tidak terarah dan hendaknya pemerintah kota berorientasi pada kepentingan dan kesejahteraan masyarakat umum.

\section{DAFTAR PUSTAKA}

Ana. 2010. Fasilitas Lengkap Perumahan. Pekanbaru: Tribun

Koestoer (Ed.). 2001. Tapak Keruangan Perkotaan. Jakarta: Penerbit UI Press.

Shinta, Dewi (Ed.). 2002. Faktor-faktor yang Mempengaruhi Pemilihan Lokasi Perumahan di Kabupaten Sleman. Yogyakarta: UGM.

Simanugkalit, P. 2010. Kiat Memilih Rumah. Pekanbaru: Tribun.

UU Nomor 4 Tahun 1992 Tentang Perumahan dan Permukiman
Keputusan Menteri Permukiman dan Prasarana Wilayah Selaku Ketua Badan Kebijaksanaan dan Pengendalian Pembangunan Perumahan dan Permukiman Nasional (BKP4N) Nomor: 217/KPTS/ M/2002 tentang Kebijakan dan Strategi Nasional Perumahan dan Permukiman (KSNPP).

Sugiyono (Ed.). 2000. Metode Penelitian Bisnis. Bandung: Penerbit Alfa Beta offset.

Ehwan, Yeri (Ed.). 2004. Analisis faktor-faktor yang mempengaruhi pemilihan perumahan di Kota Bandar Lampung. Yogyakarta: UGM

Aca Sugandhy (Eds.). 2005. Pembangunan kota Indonesia dalam abad 21). Jakarta: Lembaga Penerbit Fakultas Ekonomi Universitas Indonesia.

Febby, A. 2008. Analisis Peringkat faktorFaktor Pemilihan Lokasi Ruko dari Sudut Pandang Pengguna dan Pengembang Ruko di Kota Pekanbaru. Jurnal Saintis vol.10 No.2, Oktober: Hal 106118.

Perancangan permukiman. http://www. kuliaharsitektur.blogspot.com. Diakses tanggal 20 Februari 2009. 


\section{LAMPIRAN}

Tabel 1. Jumlah Perumahan di Kecamatan Penelitian hingga Tahun 2007

\begin{tabular}{|c|c|c|c|}
\hline No. & Kecamatan & Kelurahan & Jumlah \\
\hline \multirow[t]{5}{*}{1.} & Tampan & Sidomulyo Barat & 1845 \\
\hline & & Simpang Baru & 1829 \\
\hline & & Tuah Karya & 1498 \\
\hline & & Delima & 577 \\
\hline & & Total & 5749 \\
\hline \multirow[t]{5}{*}{2.} & Tenayan Raya & Kulim & 1782 \\
\hline & & Sail & 1145 \\
\hline & & Tangkerang Timur & 926 \\
\hline & & Rejosari & 770 \\
\hline & & Total & 4623 \\
\hline \multirow[t]{2}{*}{3.} & Bukit raya & Simpang Tiga & 256 \\
\hline & & Total & 256 \\
\hline \multirow[t]{6}{*}{4.} & Rumbai & Umban sari & 374 \\
\hline & & Sri Meranti & 239 \\
\hline & & Lembah sari & 172 \\
\hline & & Muara Fajar & 146 \\
\hline & & Rumbai Bukit & 100 \\
\hline & & Total & 1031 \\
\hline \multirow[t]{5}{*}{5.} & Marpoyan Damai & Maharatu & 599 \\
\hline & & Sidomulyo Timur & 247 \\
\hline & & Tangkerang Barat & 124 \\
\hline & & Total & 970 \\
\hline & & TOTAL & 12629 \\
\hline
\end{tabular}

Sumber: Data IMB kota Pekanbaru 2003-2007 dan hasil Analisis

Tabel 2. Jumlah Sampel di Kecamatan Penelitian

\begin{tabular}{|c|c|c|c|c|c|}
\hline No & Kecamatan & Kelurahan & Lokasi Perumahan & Jumlah Unit & Jumlah Sampel \\
\hline \multirow[t]{16}{*}{1.} & TAMPAN & Simpang Baru & Jl. Merpati Sakti & 10 & 0 \\
\hline & & & Jl. Suka Bakti & 477 & 8 \\
\hline & & & Jl. Melati & 254 & 4 \\
\hline & & & Jl. Melati & 213 & 3 \\
\hline & & & Jl. Garuda Sakti & 284 & 4 \\
\hline & & & Jl. Garuda Sakti & 296 & 5 \\
\hline & & & Jl. Mulyo & 175 & 3 \\
\hline & & & Jl.Anggrek II & $\underline{120}$ & $\underline{2}$ \\
\hline & & & Total & 1829 & 29 \\
\hline & & Sidomulyo & Jl.Purwodadi ujung & 114 & 2 \\
\hline & & Barat & Jl.Purwodadi ujung & 319 & 6 \\
\hline & & & Jl. Cipta Karya & 165 & 3 \\
\hline & & & Jl. Cipta Karya & 155 & 2 \\
\hline & & & Jl. Cipta Karya & 163 & 2 \\
\hline & & & Jl. Cipta Karya & 16 & 0 \\
\hline & & & Jl. Melur & 79 & 2 \\
\hline
\end{tabular}




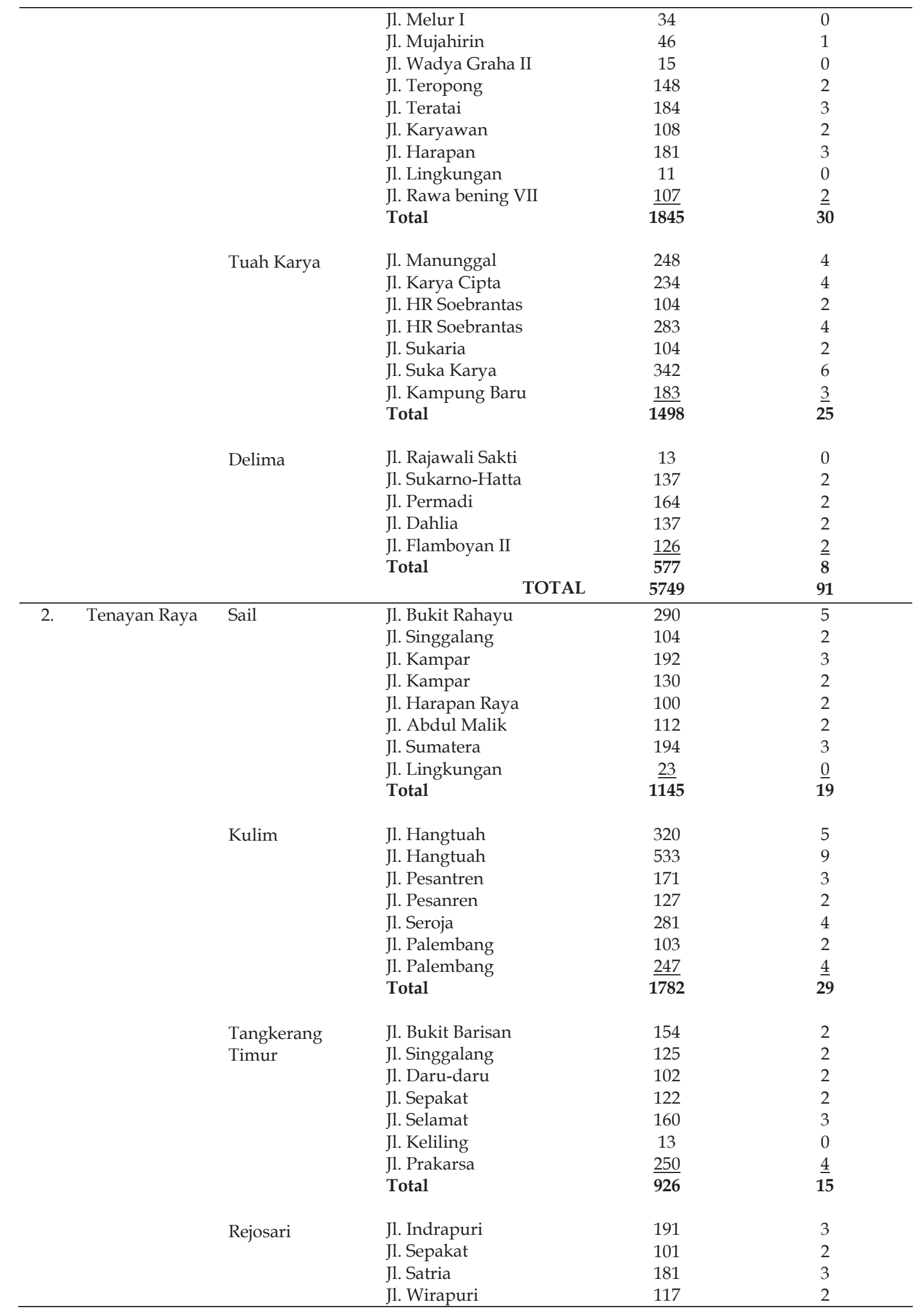

Preferensi Penghuni Perumahan di Kota (Febby Asteriani) 


\begin{tabular}{|c|c|c|c|c|c|}
\hline & & & $\begin{array}{l}\text { Jl. Duyung } \\
\text { Total }\end{array}$ & $\frac{180}{770}$ & $\frac{2}{12}$ \\
\hline & & & TOTAL & 4623 & 73 \\
\hline \multirow[t]{5}{*}{3.} & Bukit & Simpang Tiga & Jl. Aur Kuning & 15 & 0 \\
\hline & Raya & & Jl. HR Soebrantas & 109 & 2 \\
\hline & & & Jl. Ketitiran & $\underline{132}$ & $\underline{2}$ \\
\hline & & & Total & 256 & 4 \\
\hline & & & TOTAL & 256 & 4 \\
\hline \multirow[t]{8}{*}{4.} & Rumbai & Umban Sari & Jl. Gotong royong & 190 & 3 \\
\hline & & & Jl. Umban sari atas & 184 & 3 \\
\hline & & & Total & 374 & 6 \\
\hline & & Sri Meranti & Jl. Kartika Sari & 239 & 4 \\
\hline & & Lembah sari & Jl. Limbungan & 172 & 3 \\
\hline & & Muara Fajar & Jl. Yos Sudarso & 146 & 2 \\
\hline & & Rumbai Bukit & Jl. Sri Palas & 100 & 1 \\
\hline & & & TOTAL & 1031 & 16 \\
\hline \multirow[t]{7}{*}{5.} & Marpoyan & Tangkerang & Jl. Bukit Pasir & 124 & 2 \\
\hline & Damai & Barat & Jl. Karya Mandiri & 479 & 8 \\
\hline & & Maharatu & Jl. Kartama & 120 & 2 \\
\hline & & & Total & 599 & 10 \\
\hline & & & Jl.Melati & 247 & 4 \\
\hline & & Sidomulyo & & & \\
\hline & & Timur & TOTAL & 970 & 16 \\
\hline
\end{tabular}

Sumber: Data IMB kota Pekanbaru 2003-2007 dan hasil analisis

Tabel 3. Hasil Jawaban Keseluruhan Responden

\begin{tabular}{|c|c|c|c|c|c|}
\hline \multirow[t]{2}{*}{ Variabel } & \multicolumn{4}{|c|}{ Jawaban } & \multirow[t]{2}{*}{ Nilai } \\
\hline & 1 & 2 & 3 & 4 & \\
\hline \multicolumn{6}{|l|}{ I. AKSESIBILITAS } \\
\hline \multicolumn{6}{|l|}{ 1. JARAK } \\
\hline a. Kedekatan terhadap tempat kerja & 9 & 141 & 24 & 8 & 18960 \\
\hline b. Kedekatan terhadap jalan utama & 0 & 15 & 96 & 71 & 28896 \\
\hline c. Kedekatan terhadap pusat kota & 32 & 138 & 9 & 3 & 16656 \\
\hline d. Kedekatan terhadap fasilitas perdagangan & 37 & 79 & 41 & 25 & 20064 \\
\hline e. Kedekatan terhadap sarana pendidikan & 74 & 85 & 15 & 8 & 15408 \\
\hline f. Kedekatan terhadap sarana pelayanan kesehatan & 80 & 67 & 35 & 0 & 15312 \\
\hline g. Kedekatan terhadap sarana pelayanan perbankan & 20 & 153 & 7 & 2 & 17040 \\
\hline h. Kedekatan terhadap kantor pemerintahan & 93 & 75 & 16 & 4 & 14736 \\
\hline i. Kedekatan terhadap tempat rekreasi/ hiburan & 61 & 52 & 21 & 48 & 20160 \\
\hline j. Kedekatan terhadap tempat olahraga & 28 & 149 & 5 & 0 & 16368 \\
\hline k. Kedekatan terhadap terminal & 51 & 131 & 0 & 0 & 15024 \\
\hline \multicolumn{6}{|l|}{ 2.KONDISI FISIK JALAN } \\
\hline a. Kualitas permukaan jalan & 0 & 0 & 127 & 55 & 28848 \\
\hline b. Lebar jalan & 0 & 35 & 110 & 37 & 26304 \\
\hline \multicolumn{6}{|l|}{ 3.TRANSPORTASI } \\
\hline Transportasi umum (kemudahan biaya, waktu \& frekuensi) & 14 & 51 & 107 & 10 & 22896 \\
\hline $\begin{array}{l}\text { a. Transportasi pribadi } \\
\text { (Ketersediaan tempat parkir, jarak ke parkiran) }\end{array}$ & 4 & 11 & 103 & 64 & 28389 \\
\hline
\end{tabular}

\section{KELENGKAPAN PRASARANA}




\begin{tabular}{|c|c|c|c|c|c|}
\hline a. Tersedianya jaringan jalan & 0 & 10 & 85 & 87 & 29904 \\
\hline b. Tersedianya jaringan listrik & 0 & 0 & 43 & 139 & 32880 \\
\hline c. Tersedianya jaringan telepon & 11 & 158 & 10 & 3 & 17712 \\
\hline d. Tersedianya jaringan air bersih & 0 & 0 & 56 & 126 & 32256 \\
\hline e. Tersedianya jaringan drainase & 5 & 25 & 117 & 35 & 26208 \\
\hline f. Tersedianya sistem persampahan & 15 & 38 & 102 & 27 & 24240 \\
\hline \multicolumn{6}{|l|}{ III. KONDISI LINGKUNGAN } \\
\hline a. Keamanan & 0 & 0 & 135 & 47 & 28464 \\
\hline b. Kenyamanan & 9 & 18 & 106 & 49 & 26832 \\
\hline c. Kebersihan & 20 & 87 & 45 & 30 & 21552 \\
\hline d. Keindahan & 11 & 135 & 28 & 8 & 19056 \\
\hline \multicolumn{6}{|l|}{ IV. KONDISI FISIK WILAYAH } \\
\hline a. Topografi (ketinggian tanah) & 11 & 19 & 123 & 29 & 25632 \\
\hline b. Relief (kontur tanah) & 21 & 85 & 68 & 8 & 20496 \\
\hline c. Hidrologi (air tanah) & 50 & 67 & 28 & 37 & 19968 \\
\hline d. Klimatologi (Iklim) & 8 & 88 & 79 & 7 & 21552 \\
\hline \multicolumn{6}{|l|}{ V. KONDISI SOSIAL EKONOMI } \\
\hline a. Harga Perumahan & 0 & 7 & 28 & 147 & 32928 \\
\hline b. Kemudahan Pengajuan kredit & 10 & 18 & 92 & 62 & 27360 \\
\hline c. Penetapan biaya DP\&kemudahan pembayaranDP & 34 & 89 & 43 & 16 & 19440 \\
\hline d. Pemberian Discount & 49 & 107 & 23 & 3 & 16512 \\
\hline e. Pemberian Bonus/hadiah & 23 & 128 & 21 & 10 & 18336 \\
\hline f. Kualitas Pelayanan & 52 & 47 & 78 & 5 & 19200 \\
\hline g. Iklan Penjualan & 22 & 93 & 65 & 2 & 19728 \\
\hline \multicolumn{6}{|l|}{ VI. KUALITAS PERUMAHAN } \\
\hline a. Spesifikasi Perumahan & 9 & 14 & 73 & 86 & 28800 \\
\hline b. Desain Perumahan & 21 & 84 & 62 & 15 & 20880 \\
\hline \multicolumn{6}{|l|}{ VII. KEPENDUDUKAN } \\
\hline a. Jumlah Penduduk & 6 & 45 & 88 & 43 & 25536 \\
\hline b. Kepadatan Penduduk & 32 & 78 & 52 & 20 & 20352 \\
\hline \multicolumn{6}{|l|}{ VIII.KELENGKAPAN FASILITAS PERUMAHAN } \\
\hline a. Kelengkapan Fasilitas Umum (Fasum) & 9 & 11 & 117 & 45 & 26976 \\
\hline b. Kelengkapan Fasilitas Sosial (Fasos) & 13 & 95 & 63 & 11 & 20928 \\
\hline \multicolumn{6}{|l|}{ IX. ASPEK LEGALITAS PERUMAHAN } \\
\hline a. Keabsahan kepemilikan perumahan & 0 & 0 & 85 & 97 & 30864 \\
\hline \multicolumn{6}{|l|}{ X. ASPEK TEKNIS PELAKSANAAN } \\
\hline a. Bukan daerah banjir, gempa dll. & 9 & 15 & 137 & 21 & 25632 \\
\hline b. Kemudahan pencapaian tanpa hambatan yang berarti & 15 & 30 & 88 & 49 & 25680 \\
\hline c. Kondisi tanah baik & 4 & 17 & 99 & 62 & 27984 \\
\hline $\begin{array}{l}\text { XI. ASPEK KESEHATAN } \\
\text { a. Lokasi sebaiknya jauh dari lokasi pabrik yang dapat } \\
\text { mendatangkan polusi }\end{array}$ & 3 & 8 & 117 & 54 & 28128 \\
\hline b. Lokasi sebaiknya tidak terlalu terganggu kebisingan & 14 & 15 & 105 & 48 & 26448 \\
\hline
\end{tabular}

Sumber: Hasil Analisis 
Tabel 4. Variabel yang Merupakan Unsur dalam Faktor Pemilihan Lokasi Perumahan

VARIABEL

I. AKSESIBILITAS

1. JARAK

Kedekatan terhadap jalan utama

2. KONDISI FISIK JALAN

a. Kualitas permukaan jalan

b. Lebar jalan

3. TRANSPORTASI

a. Transportasi umum (kemudahan biaya, waktu dan frekuensi)

b. Transportasi pribadi (Ketersediaan tempat parkir, jarak ke parkiran)

II. KELENGKAPAN PRASARANA

a. Tersedianya jaringan jalan

b. Tersedianya jaringan listrik

c. Tersedianya jaringan air bersih

d. Tersedianya jaringan drainase

III. KONDISI LINGKUNGAN

a. Keamanan

b. Kenyamanan

IV. KONDISI SOSIAL EKONOMI

a. Harga Perumahan

b. Kemudahan pengajuan kredit

V. KONDISI FISIK WILAYAH

a. Topografi (ketinggian tanah)

VI. KUALITAS PERUMAHAN

a. Spesifikasi Perumahan

VII. KEPENDUDUKAN

a. Jumlah Penduduk

VIII. KELENGKAPAN FASILITAS PERUMAHAN

a. Kelengkapan Fasilitas Umum (Fasum)

IX. ASPEK LEGALITAS PERUMAHAN

a. Keabsahan kepemilikan perumahan

$X$. ASPEK TEKNIS PELAKSANAAN

a. Bukan daerah banjir, gempa dll.

b. Kemudahan pencapaian tanpa hambatan yang berarti

c. Kondisi tanah baik

XI. ASPEK KESEHATAN

a. Lokasi sebaiknya jauh dari lokasi pabrik yang dapat mendatangkan polusi

b. Lokasi sebaiknya tidak terlalu terganggu kebisingan

Sumber: Hasil analisis 


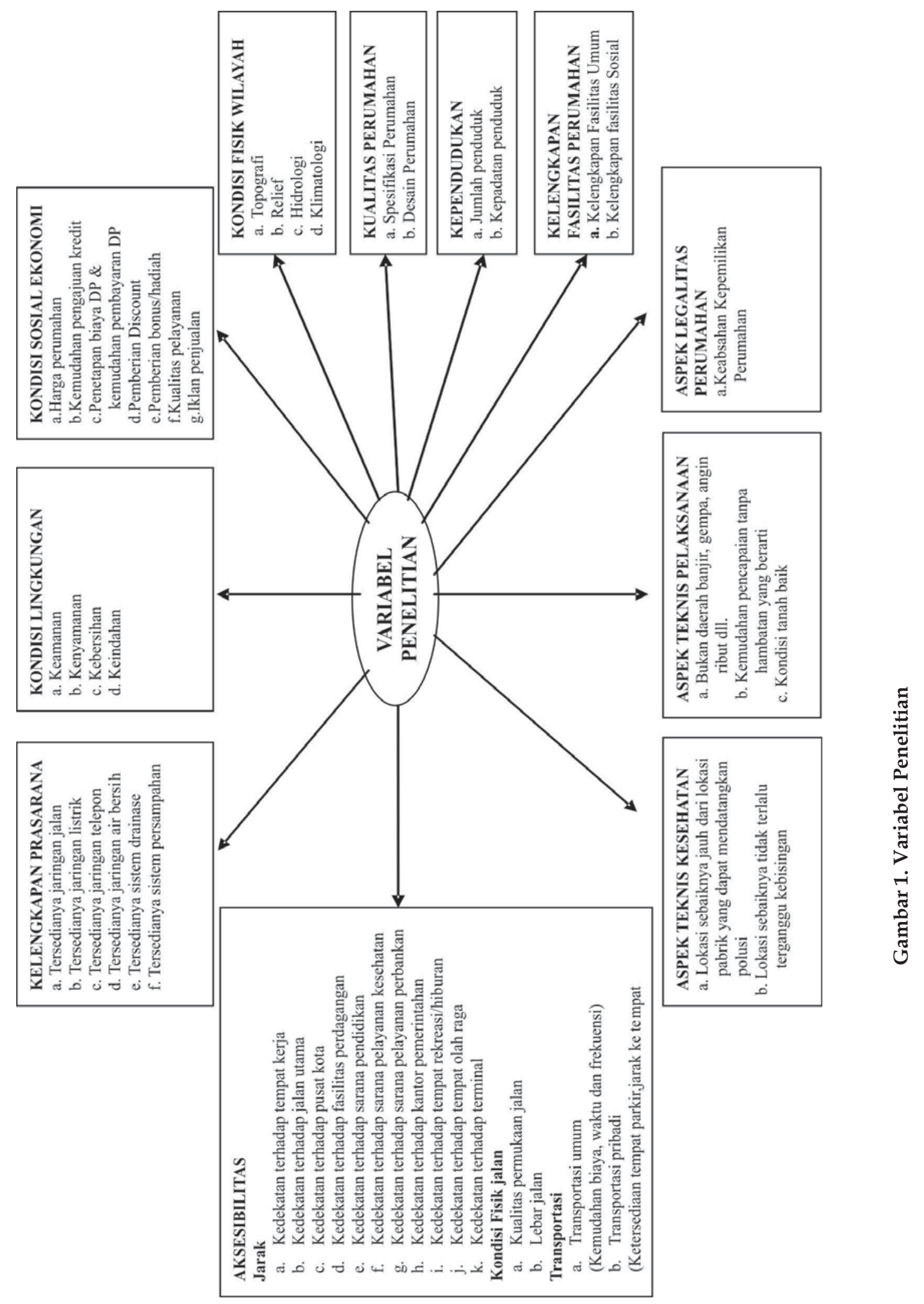

